\title{
Study on the Relationship between Working Ability and Working Performance of Health Personnel in Township Health Centers
}

\section{-- An Empirical Study based on Word Frequency Analysis of Interviews}

\author{
Jiaxu Lou \\ School of Public Health and Management, Wenzhou Medical University, Wenzhou, China \\ loujiaxu0620@163.com
}

\begin{abstract}
Objective: To describe the status quo and influencing factors of the work ability and work performance of health personnel in township health centers, and to explore the relationship mechanism between them. Methods: Using a multi-class stratified sampling method, semi-structured personal in-depth interviews were conducted with 182 health personnel in 45 township health centers, word frequency analysis was performed on relevant content, and a framework of mediating effects of work motivation was constructed to analyze the effect of work ability on work performance. Results: The main factors to improve the working ability of health personnel are education and training, and the main factors that restrict working ability are external conditions and personnel qualification restrictions; among the factors that affect work performance, human resources are the primary human factor, income level is the primary economic factors and interpersonal relationship is the primary environmental factor. Conclusion: Continuing education, self and social identity have a positive impact on the improvement of health personnel's work ability and behavioral performance, economic factors have a negative impact on health personnel's satisfaction, and the new medical reform policy has both positive and negative impact on it. Work motivation produces a mediating effect between the work ability and work performance of health workers.
\end{abstract}

Keywords: Township Health Centers; Health Personnel; Work Ability; Work Performance; Mediation Effect.

\section{Introduction}

Township health centers are the intermediate hub of establishing and developing rural three-level health care network in China and the focus of health service policy after the new medical reform, which is an important link to promote the reform and development of grassroots health care system. If its medical service capacity is limited, it will seriously affect the process of medical reform such as graded diagnosis and treatment [1-2]. Health personnel as the most vigorous human resource in township health centers, their capability of providing medical services work (including physical ability, mental ability, psychological conditions, etc.) as well as the continuing education training learning is closely related to the quality and efficiency of rural health service, having a direct impact on citizens' life and health [3-4]. State Council's Opinions on Implementing the "Healthy China" Initiative put forward the requirements of strengthening the training of health personnel, in order to achieve the goal of improving the health level of the whole people [5]. However, at present, the expected performance goal of rural health institutions in China is still limited by the actual post competency of health service personnel, and the talent team of township health centers needs to be continuously built. Previous studies have found that there is a positive correlation relationship between health workers' ability to work and their task performance and relationship performance. [6] The internal work motivation can play a role of intermediary intervention on personnel work direction and degree of effort to impact their work performance [7-9]. But most studies focus on the single factor analysis of a single variable. There is no systematic study on the relationship among the three or their mechanism of action. Accordingly, with the aid of conversation analysis and word frequency analysis, this research detailly discusses the current situation of primary health personnel's ability to 
work and work performance, influence factors and their correlation, build a framework model of work motivation as an intervening variable, to improve the quality of health personnel, realize sustainable development of rural health medical institutions to provide reference.

\section{Subjects and Methods}

\subsection{Survey Subjects}

Multi-class stratified sampling was used. The eastern, central and western provinces of Shandong, Anhui and Shaanxi were selected separately. Then 3 counties were chosen according to the geographical location and economic development level of each province. Five township health centers were selected according to geographical orientation in each county, with 45 township hospitals in total. Convenient sampling was adopted in each township health center. The director (person in charge), a doctor, a nurse and a public health worker were selected to conduct semistructured in-depth personal interviews, and the whole process was recorded with the informed consent of the respondents. 182 people were interviewed. Among them, 61 are from Shandong province, 60 from Anhui province and 61 from Shaanxi Province. There were 44 deans (directors), 49 doctors, 44 nurses and 45 public health workers.

\subsection{Survey Methods}

The self-made interview outline was used as an interview tool to investigate the respondents. The following is a partial list of questions related to the competence and performance of health personnel.

"What is the current state of competence of the hospital's staff? Is it adequate for the work of the center?"

"What training does the center currently carry out or participate in, and has it effectively improved the staff's working ability?"

"Do you feel that you and your colleagues are fully qualified for the job? Which factors have the greatest impact on job performance?"

"How do you feel about the quality or efficiency of your work? What factors affect the quality or effectiveness of your work?"

"How do you treat your colleagues? How do you feel about your relationships with your colleagues?"

\subsection{Data Analysis}

In this study, the recorded interview was transformed into text for discourse analysis. In this study, Maxqda, a qualitative analysis software, is used to organize and encode the text content. Under the working ability theme, set two subject directories, "Improving working ability" and "Limiting working ability". Under the theme of "work performance", three subject directories are set up: "human factor", "economic factor" and "environmental factor". In this study, word frequency analysis was carried out on the text contents in each catalog, and the high frequency and related terms were extracted, and the results were formed through classification and integration.

\section{Results}

\subsection{Working Ability}

In terms of factors affecting the improvement of work ability, health personnel mentioned training, study, further education, practice, etc., which represented education and training, the most frequently, 131 times in total. In addition, education level, professional spirit and policy were also included, with word frequency of 97, 11 and 3 respectively. In terms of limiting work ability, external factors such as technology, equipment, computer, base, configuration and environment were mentioned the most, with a total of 63 times, as well as personnel qualification restrictions, work pressure and policy 
factors. Policy factors can both improve and limit work capacity, with positive and negative effects (Table 1).

Table 1. Interview Word Frequency Analysis of Influencing Factors of Work Ability

\begin{tabular}{|c|c|c|c|}
\hline $\begin{array}{c}\text { Theme } \\
\text { Directory }\end{array}$ & $\begin{array}{l}\text { Factor (word } \\
\text { frequency) }\end{array}$ & $\begin{array}{l}\text { Entry (word } \\
\text { frequency) }\end{array}$ & Example \\
\hline \multirow[t]{4}{*}{$\begin{array}{c}\text { Improve } \\
\text { work ability }\end{array}$} & $\begin{array}{l}\text { Education and } \\
\text { Training (131) }\end{array}$ & $\begin{array}{l}\text { Training (62) } \\
\text { Learning (44) } \\
\text { Further study } \\
\quad(14) \\
\text { Practice (11) }\end{array}$ & $\begin{array}{l}\text { We have regular training. The business ability is ok. } \\
\text { Workers will not feel inadequate. (Public Health, } \\
\text { Liangshan, Shandong province) }\end{array}$ \\
\hline & $\begin{array}{c}\text { Education level } \\
\text { (97) }\end{array}$ & $\begin{array}{c}\text { Knowledge } \\
(47) \\
\text { Major (37) } \\
\text { Experience (7) } \\
\text { Education (6) }\end{array}$ & $\begin{array}{c}\text { The first one should be business knowledge. We have a } \\
\text { large amount of knowledge in health care, so we should } \\
\text { improve our ability by constantly learning and } \\
\text { supplementing professional knowledge. (Public Health, } \\
\text { Hanyin, Shaanxi) }\end{array}$ \\
\hline & $\begin{array}{c}\text { Professionalism } \\
\text { (11) }\end{array}$ & $\begin{array}{l}\text { Responsibility } \\
\quad(4) \\
\text { Dedication (2) } \\
\text { Positiveness (5) }\end{array}$ & $\begin{array}{l}\text { In terms of ability, people are also very simple. Our } \\
\text { country mainly expresses a concept that people's sense of } \\
\text { responsibility is important. As long as people have a } \\
\text { sense of responsibility, they can do things. (Dingyuan, } \\
\text { Anhui, doctor) }\end{array}$ \\
\hline & Policy Factors (3) & $\begin{array}{l}\text { Medical } \\
\text { Reform (3) }\end{array}$ & $\begin{array}{l}\text { It is the same thing to say that according to the current } \\
\text { functions of our health centers, they will be competent } \\
\text { after the medical reform. (Guzhen, Anhui, Person in } \\
\text { charge) }\end{array}$ \\
\hline \multirow[t]{4}{*}{$\begin{array}{l}\text { Limited } \\
\text { ability to } \\
\text { work }\end{array}$} & $\begin{array}{c}\text { External } \\
\text { Constraints (63) }\end{array}$ & $\begin{array}{c}\text { Technology } \\
(21) \\
\text { Equipment (12) } \\
\text { Computer (13) } \\
\text { Base level (13) } \\
\text { Configuration } \\
(2) \\
\text { Environment } \\
(2)\end{array}$ & $\begin{array}{l}\text { I can solve all the simple problems, but the hard ones are } \\
\text { too complex to solve. After all, the hospital equipment } \\
\text { conditions also have problems. (Lujiang, Anhui, Doctor) }\end{array}$ \\
\hline & $\begin{array}{c}\text { Personnel } \\
\text { Qualification } \\
\text { Restrictions (13) }\end{array}$ & $\begin{array}{c}\text { Age (9) } \\
\text { Title (2) } \\
\text { Promotion (2) }\end{array}$ & $\begin{array}{l}\text { Some older employees can do basic work well, but some } \\
\text { may have a little difficulty in doing it, because some } \\
\text { knowledge is not understood and they are slow to accept } \\
\text { new things. (Dingyuan, Anhui, President) }\end{array}$ \\
\hline & $\begin{array}{l}\text { Working Stress } \\
\text { (12) }\end{array}$ & $\begin{array}{l}\text { Workload (6) } \\
\text { Pressure (4) } \\
\text { Burden (2) }\end{array}$ & $\begin{array}{l}\text { But because the workload is too large, the time can be } \\
\text { used to read and study is very little. We can only find } \\
\text { what problem do not understand, check the Internet, } \\
\text { know more about it. (Guzhen, Anhui, Doctor) }\end{array}$ \\
\hline & $\begin{array}{l}\text { Policy Factors } \\
\text { (10) }\end{array}$ & $\begin{array}{l}\text { Referral (5) } \\
\text { Medical } \\
\text { Reform (3) } \\
\text { System (2) }\end{array}$ & $\begin{array}{l}\text { After the medical reform, no one came to the hospital. } \\
\text { We are running mainly outpatient, who are having } \\
\text { common diseases, very simple. Serious diseases are } \\
\text { referred to the township hospital or county hospital } \\
\text { (Anhui Guzhen, doctor) }\end{array}$ \\
\hline
\end{tabular}

\subsection{Job Performance}

In terms of human factors affecting the performance of health workers, professional title, ability, educational background, age, specialty, skill and other representative human resource factors received the most feedback, totaling 140 times. Education and training, self-efficacy and job stress were 75, 64 and 64 times, respectively. In terms of economic factors, wage, income level, income gap and other factors represent income level and welfare security. Word frequency was 82 and 68, respectively. In terms of environmental factors, health workers considered interpersonal relationships 
such as colleagues and leaders to have a great impact, and a total of 74 articles were mentioned. There are also working conditions, management policies, a sense of fairness and social identity (Table 2).

Table 2. Interview Word Frequency Analysis of Influencing Factors of Job Performance

\begin{tabular}{|c|c|c|c|}
\hline $\begin{array}{l}\text { Theme } \\
\text { directory }\end{array}$ & $\begin{array}{c}\text { Factor (word } \\
\text { frequency) }\end{array}$ & $\begin{array}{c}\text { Entry (word } \\
\text { frequency) }\end{array}$ & Example \\
\hline \multirow[t]{4}{*}{ Human factors } & $\begin{array}{l}\text { Human } \\
\text { Resources } \\
\text { (140) }\end{array}$ & $\begin{array}{l}\text { Title (46) } \\
\text { Ability (31) } \\
\text { Education (24) } \\
\text { Age (18) } \\
\text { Major (16) } \\
\text { Skills (5) }\end{array}$ & $\begin{array}{l}\text { I want to gradually work hard to pass the professional } \\
\text { title examination to the intermediate level, improve my } \\
\text { operation level, increase business volume, and better } \\
\text { reflect the value of my education. (Guzhen, Anhui, } \\
\text { Doctor) }\end{array}$ \\
\hline & $\begin{array}{l}\text { Education and } \\
\text { Training (75) }\end{array}$ & $\begin{array}{l}\text { Training (35) } \\
\text { Learning (23) } \\
\text { Further study } \\
\quad \text { (9) } \\
\text { Education (8) }\end{array}$ & $\begin{array}{l}\text { After returning from the training, I treated all the } \\
\text { patients in the department of cardiology with } \\
\text { complicated conditions, including the department of } \\
\text { neurology. cerebral infarction and cerebral thrombosis. I } \\
\text { can't do it without training. Because I'm afraid I'm not } \\
\text { able to. After seeing more outside, it's easier for me to } \\
\text { do the operation. (Hanyin, Shaanxi, President) }\end{array}$ \\
\hline & $\begin{array}{l}\text { Self-efficacy } \\
\text { (64) }\end{array}$ & $\begin{array}{l}\text { Initiative (31) } \\
\text { Sense of } \\
\text { Achievement } \\
\quad(12) \\
\text { Satisfaction (8) } \\
\text { Value (8) } \\
\text { Responsibility } \\
\quad(5)\end{array}$ & $\begin{array}{l}\text { I can still do the job here, and it makes sense to do it. } \\
\text { We now take care of chronic diseases, reducing } \\
\text { complications and disability and improving the quality } \\
\text { of life of patients. People are more grateful to us, and } \\
\text { we also have a certain sense of achievement. (Zhao } \\
\text { Yuan, Shandong, doctor) }\end{array}$ \\
\hline & $\begin{array}{l}\text { Working stress } \\
\text { (64) }\end{array}$ & $\begin{array}{l}\text { Pressure (30) } \\
\text { Workload (29) } \\
\text { Working Hours } \\
\quad(5)\end{array}$ & $\begin{array}{c}\text { The way we feel right now is we don't have enough } \\
\text { people. There are not many front-line clinical staff. } \\
\text { More stress at work, less ability to serve patients. } \\
\text { Doctor-patient relations are also strained. (Lujiang, } \\
\text { Anhui, Doctor) }\end{array}$ \\
\hline \multirow[t]{2}{*}{$\begin{array}{l}\text { Economic } \\
\text { factors }\end{array}$} & $\begin{array}{c}\text { Income level } \\
(82)\end{array}$ & $\begin{array}{l}\text { Salary (67) } \\
\text { Income level } \\
\quad(12) \\
\text { Income gap (3) }\end{array}$ & $\begin{array}{c}\text { Now the salary itself is too low. Less performance, less } \\
\text { pay. The imbalance in the workers' mind affects their } \\
\text { enthusiasm even more. (Shandong Yucheng, Public } \\
\text { Health) }\end{array}$ \\
\hline & $\begin{array}{c}\text { Welfare } \\
\text { Security (68) }\end{array}$ & $\begin{array}{l}\text { Welfare (22) } \\
\text { Subsidy (20) } \\
\text { Bonus (12) } \\
\text { Insurance (8) } \\
\text { Guarantee (6) }\end{array}$ & $\begin{array}{l}\text { Before when the unit benefit is good, we still have the } \\
\text { welfare that prevents summer heat to drop in } \\
\text { temperature. I'm not happy with the current state of } \\
\text { work benefits. Now it doesn't reflect the value of my } \\
\text { labor, now it's less motivated. (Guzhen, Anhui, } \\
\text { Nursing) }\end{array}$ \\
\hline \multirow[t]{3}{*}{$\begin{array}{l}\text { Environmental } \\
\text { factors }\end{array}$} & $\begin{array}{c}\text { Personal } \\
\text { Relationships } \\
\text { (74) }\end{array}$ & $\begin{array}{l}\text { Colleagues (42) } \\
\text { Leadership (16) } \\
\text { Personal } \\
\text { Relationships } \\
\quad(16) \\
\end{array}$ & $\begin{array}{l}\text { We are very united, and the leader attaches great } \\
\text { importance to me. There is a good rapport among } \\
\text { colleagues and I feel comfortable working here. (Public } \\
\text { Health, Liangshan, Shandong province) }\end{array}$ \\
\hline & $\begin{array}{l}\text { Working } \\
\text { Conditions } \\
\text { (67) }\end{array}$ & $\begin{array}{l}\text { Equipment (23) } \\
\text { Condition }(20) \\
\text { Environment } \\
\quad(18) \\
\text { Transportation } \\
\quad(6) \\
\end{array}$ & $\begin{array}{l}\text { Working conditions are not good enough. For example, } \\
\text { computers, networks and other equipment, although } \\
\text { they have, but the computer is too slow, the speed of the } \\
\text { network is too slow. Work efficiency is affected when } \\
\text { there are too many people. (Public Health, Lujiang, } \\
\text { Anhui) }\end{array}$ \\
\hline & $\begin{array}{l}\text { Management } \\
\text { Policy (55) }\end{array}$ & $\begin{array}{l}\text { Policy (30) } \\
\text { Management } \\
\text { (25) }\end{array}$ & $\begin{array}{l}\text { This policy helps hospitals. The business of the hospital } \\
\text { to bring up the skills, their own business to better serve } \\
\text { the local people. (Sanyuan, President of Shaanxi } \\
\text { Province) }\end{array}$ \\
\hline
\end{tabular}




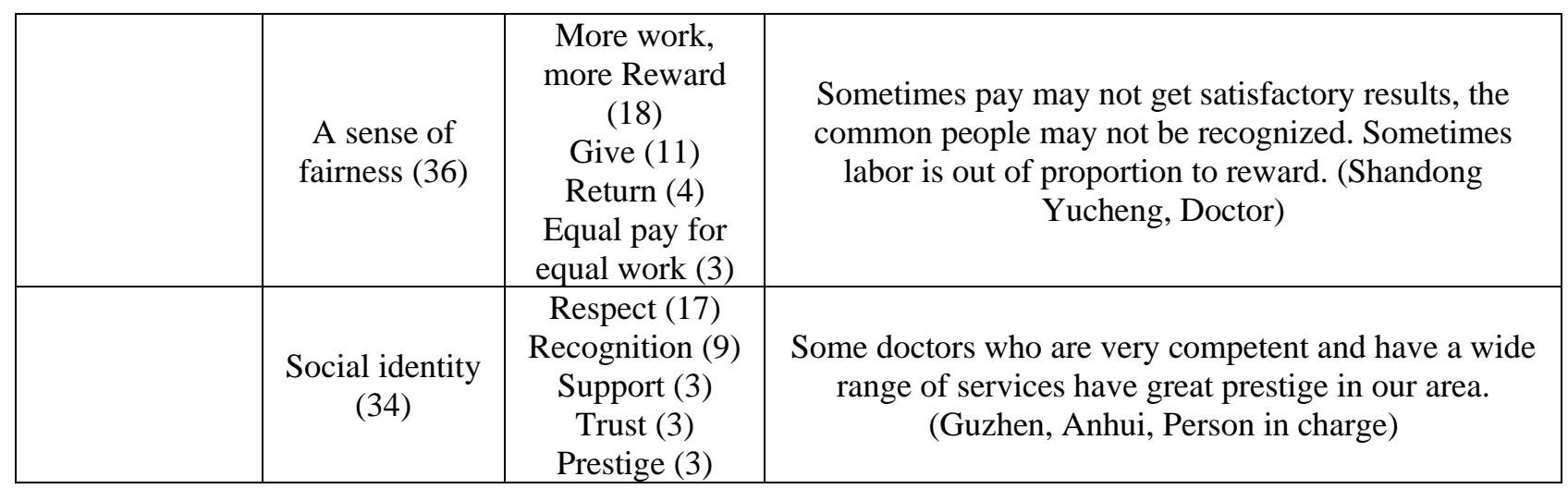

\section{Discussion}

\subsection{Continuing Education being Significant to the Improvement of the Working Capacity and Performance of Health Personnel}

The ability and quality of health personnel in township hospitals determines the quality of primary medical and health services. A large number of studies have shown that training, further education and other continuing education measures have positive feedback on the working ability and performance of health workers. [10] In this study, education and training are the most discussed factors affecting work ability and performance, proving that continuing medical education can benefit health personnel in medical service technical level and performance results. First, the comprehensive quality of health personnel in township health centers is not high, with low educational background. This shows that their professional knowledge and professional experience during their college education are already limited. In the interview, some employees also expressed that they need continuous learning to meet the requirements of their job. In addition, the training has effectively improved their medical quality and technical ability. Some employees volunteered to increase training opportunities to help improve their business. Therefore, in order to match the job requirements, continuing education to improve the level of medical services is imperative. Secondly, continuing education for grass-roots health workers is conducive to higher job identity, which is of great significance for improving the job satisfaction of the population [11]. According to the two-factor theory, satisfaction as a motivating factor can improve work enthusiasm [12]. Health workers prefer to put more energy into their work, which has a positive effect on the quality of medical service. At present, there are some problems in the continuing education system of township health centers, such as short training time, insufficient number of times, and unclear demand orientation, which will cause losses to the professional level, service quality and future development of health personnel if not improved.

\subsection{The New Medical Reform Policy Having Positive and Negative Effects on the Improvement of Medical Service Capacity and Quality of Health Personnel}

Based on the Opinions on Deepening the Reform of the Medical and Health system, the new round of reform of the medical and health system in China has been carried out in all fields in accordance with the principle of "ensuring the basic level, strengthening the grass-roots level and building the mechanism", and the requirements of building the grassroots medical and health personnel team have been put forward [13]. This study found that the new medical reform is both an opportunity and a challenge for primary medical service institutions. It also has positive and negative effects on the medical service personnel in township hospitals. Undeniably, the number of policies increased after the new medical reform, and the intensity was significantly stronger than before the reform [14]. However, in the interview process, we saw the "mixed feelings" of grassroots health workers. For example, the service hardware of primary-level health and medical institutions has been significantly strengthened after the new medical reform. The input of instruments and equipment and the 
improvement of office environment have enabled health workers to have better working conditions and meet part of their survival needs. This is conducive to improving the enthusiasm of the work, and increases the guarantee of the diagnosis and treatment results and quality of patients. On the other hand, due to the structural limitations of rural health manpower resources, older health workers in medical institutions report difficulty in using the "new technology" of computers, which leads to their inability to adapt to normal work. This has a negative impact on work mood and service efficiency. Another example is the referral system set up under the hierarchical diagnosis and treatment system. After patients with critical and rare diseases in township hospitals are transferred to county or above medical institutions, the working pressure of grass-roots health workers is relieved. Most of the respondents said they were competent to work after the medical reform. But the reason is that the task difficulty of township health centers is reduced rather than the individual ability is improved. This will lead to a weakening of the existing physical capacity of health personnel. Latent abilities are not developed, and then practical abilities cannot be further developed. This is contrary to the goal of "improving the capacity of primary health care services".

\subsection{Self-identity and Social Identity Compensating for the Dissatisfaction of Health Workers Caused by Economic Factors}

According to Herzberg's two-factor theory, economic factors such as salary and welfare are health factors and cannot satisfy health workers. Achievement, responsibility, respect, trust, recognition and other factors representing self and social identity are motivation factors, which can bring satisfaction to employees. These really have the effect of motivating people to work. [11] This paper also confirmed this theory. this study in terms of hygiene factors, low-income level, inadequate protection of the benefits and problems such as unbalanced investment returns is in towns and townships health workers commonly complain and claim, which has seriously impaired the work enthusiasm of the employees, reduced job satisfaction, and self-efficacy, and even generate turnover intention, The dedication of health workers is negatively affected in the form of reduced productivity. The reason why health personnel can still maintain good task performance is that the satisfaction caused by incentive factors makes up for the dissatisfaction caused by health factors. Among all the motivating factors, Self-identity and social identity have a positive incentive effect on job identity (job cognition, behavioral tendency, values, sense of belonging) and job performance, and the effect is the largest [15]. This is also because it meets the higher level of growth needs in ERG theory. Most grass-roots health workers said that working in township health centers has low risk of doctor-patient relationship and can be respected by the public. They tend to have a sense of accomplishment at work and promote internal work motivation. In addition, positive self-and social identity mostly predicted good relationship performance. In a harmonious working atmosphere, health workers can actively maintain a harmonious interpersonal relationship with colleagues and leaders.

\subsection{Work Motivation Having a Mediating Effect between Health Workers' Work Ability and Job Performance}

As can be seen in Table 2 above, according to the results of the professional spirit of terms such as responsibility, dedication and work including entry workload, work burden pressure, respectively, to the health workers ability is improvement and restrictions. As in table 3 there is responsibility, value and work time, pressure and other similar factors affecting health personnel's job performance. In the category of work motivation, work motivation and work pressure belong to the cognition of incentive mechanism and affect the performance of employees' work behavior [7]. This indicates that work ability can directly affect job performance and indirectly affect job performance through work motivation. That is, work motivation plays a mediating role in the influence of work ability and job performance. In the word frequency analysis of influencing factors of job performance, ability plays a large part in human factor. Many health workers express that the medical service quality of individuals or organizations is limited by their professional level and technical ability, which is the same as the conclusion of Yang et al. [6] who studied the positive correlation between work ability 
and job performance. Education and training, education level, working conditions and other factors that affect work ability also have positive feedback on work performance. Employees with high level of competence have an advantage in terms of the degree and speed at which they master knowledge and skills. This will help them achieve their work objectives, maintain high work efficiency and improve their overall performance [14]. Of course, the level of competence is a necessary but not sufficient condition for achieving good behavioral performance. Work ability can only reflect the possibility of completing tasks in a certain job, without strong motivation, behavior will still be empty talk. First of all, according to the expectation theory, when employees are not given valuable rewards or rewards after their efforts bring high performance and lack rationality and fairness, their enthusiasm cannot be adjusted and they lose the motivation to output high quality service.

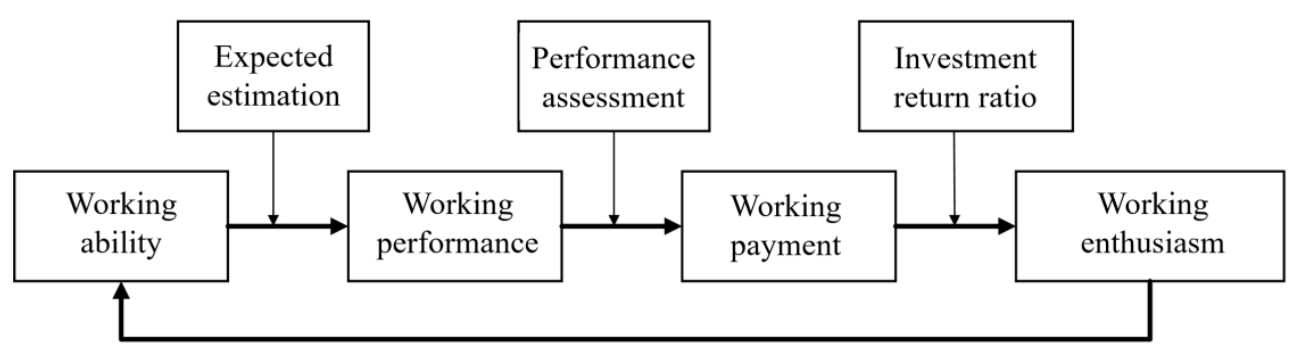

Figure 1. Theoretical Model of Health Worker Expectation

During the survey, some health workers said that the pay was not proportional to the return. In the case of the same pay, the sense of gap is formed through the vertical comparison with the salary of county-level hospitals or superior hospitals. Cause unfair and dissatisfied emotions, and have a negative impact on job performance. Secondly, according to the theory of job stressors, lack of job skills and high job requirements are common job stressors. As the key focus of the goal of "strengthening the construction of basic health service talent team" in the new medical reform, the workload of health personnel in township health centers has increased significantly. The society puts forward higher requirements for its medical and health service level. Workload and work quality are also the main indicators of performance appraisal. The work pressure of grass-roots health workers has increased sharply. Concerns about job competence put health workers under high pressure. It seriously reduces the self-efficacy of health workers, which has an adverse impact on job performance. To sum up, this study establishes the relationship framework among work ability, work motivation and work performance as shown in Figure 1.

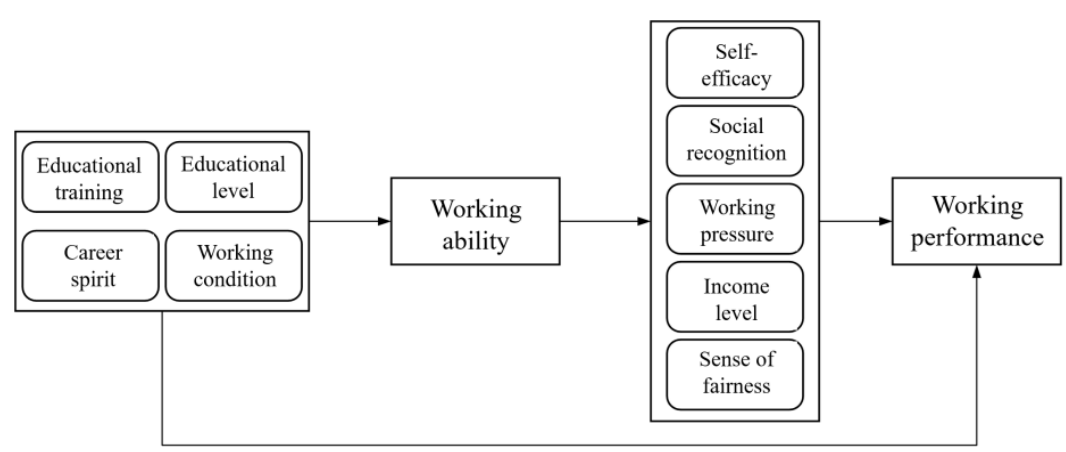

Figure 2. Relationship Framework Between Working Ability, Working Motivation and Working Performance

\section{Suggestions}

Firstly, the model of continuing medical education and effectively improve the service quality of health personnel needs to be improved. The improvement of health workers' working ability is not achieved overnight, and lifelong learning needs to be realized through continuing education and 
training. To begin with, determine the training content according to the job needs of health workers in township health centers, and carry out targeted counterpart support to avoid ineffective training. Second, combined with Internet online education, a distance teaching center can be set up. The superior hospital can radiate information to the township health centers through the remote system, ensure the learning time and training times of health personnel, meet their needs of independent learning, and improve their satisfaction with continuing medical education. This can improve the medical service quality of grass-roots health personnel. Secondly, the government can give play to the synergy of medical reform policies to solve the worries of talent development. The policies in the new medical reform should not be implemented independently. Only when they are linked together to form a synergistic effect can they really give full play to their maximum effectiveness. For example, in terms of training policies, while strengthening health and medical training, we can give consideration to the guidance and education of computer, instrument and equipment and other operating technologies. This makes the health talents of township health centers in line with the diagnosis and treatment means in the new century, and improves their technical level and work efficiency. In addition, the government can improve the construction of hierarchical diagnosis and treatment system, clarify the scope of medical services provided by township health centers and the functional orientation of undertaking chronic disease rehabilitation, force the ability of grass-roots health personnel to improve and help the quality of grass-roots medical services [16]. Third, the government can reasonably improve the performance evaluation methods and promote the internal incentive of performance objectives. On the one hand, we need to weaken the negative impact of the external motivation of economic factors on the health personnel of township health centers. The government should distribute performance pay according to the principle of more work and more pay. The government should let health workers feel a reasonable pay return ratio from an appropriate gap, and improve their sense of fairness and enthusiasm. On the other hand, the government can take patient satisfaction, work attitude and quality as the primary indicators of performance evaluation, internalize work motivation, and help health workers obtain higher internal incentives such as self and social identity.

\section{References}

[1] Topp, S., Julien, C., \& Johanna, H. Understanding the dynamic interactions driving Zambian health centre performance: a case-based health systems analysis. Health policy and planning, 2015, 30(4): 485-99.

[2] Zhou, Y., \& Fang, P. Analysis of capacity promotion pathway in rural primary healthcare institutions under hierarchical diagnosis and treatment system. Chinese Hospitals, 2017,21(09):12-15.

[3] Yang, J., Lv, Z., Wang, X., Huang, H., Li, L., Wang, Y., \& Chen, S. Comparative Study on the Construction of Rural Health Care Personnel in Township Hospital Centers in China before and after the New Medical System Reform Policy. Chinese General Practice, 2014, 17(16): 1875-1879+1883.

[4] Guo, M., Wu, Q., Yuan, L., Gao, L., \& Liang, L. Study on Work Ability and Influencing Factors of Community Health Service Personnel in Heilongjiang Reclamation Area. Chinese Journal of Social Medicine,2016, 33(01): 68-71.

[5] State Council of the People's Republic of China. Opinions of the State Council on Implementing the Healthy China Initiative. Gazette of the State Council of the People's Republic of China [2019] No. 13.

[6] Yang, L., Wang, L., \& Lü, D. Study on the Relationship Among Team Performance, Nursing Staff Teamwork and Work Ability. Chinese Hospital Management, 2018, 38(07): 67-69.

[7] Yuan, B., \& Meng, Q. Behavior Determinants of Rural Health Workers: Based on Work Motivation Theory Analysis. Chinese Health Economics, 2012, 31(07): 50-52.

[8] Yuan, B., Meng, Q., Hou, Z., Sun, X., \& Song, K. Analysis on incentive mechanism and motivation of rural health providers. Chinese Journal of Health Policy, 2010, 3(10): 3-9.

[9] Zhang, Y., Pang, D., Chen, D., Tai, C., \& Sui, S. Mediating effect of internal motivation on job insecurity and job performance among nurses. Journal of Nursing Administration, 2020, 20 (09): 609-613. 
[10] Wu, M., Liu, Y., Mu, Y., \& He, Y. Job performance of health technicians in township hospitals and the influencing factors. Chinese Rural Health Service Administration, 2020,40(05):330-334.

[11] Zhao, D., Chen, J., Chen, M., \& Hu, D. Research on the current situation of health human resources in rural areas of northern Jiangsu [J]. Journal of Community Medicine,2016, 14(07): 38-40.

[12] Cheng, Y., Peng, L., Li, J., \& Jia, D. Study on incentive of dispatched personnel in hospital from the perspective of two-factor theory. Jiangsu Health System Management,2021,32(04):441-444.

[13] Shan, D. Ten years and Future prospect of China's medical reform. Heilongiiang Social Sciences, 2020(06):82-88.

[14] Xiong Y. Medical and health system reform from the perspective of policy tools: Review and prospect -based on textual analysis of medical and health policies from 1978 to 2015. Social Security Research, 2016(03):51-60.

[15] Yang S. Research on incentive of rural grass-roots health technicians in Zhejiang Province. Zhejiang University, 2020.

[16] Yang L., Wang, L., Lv, D., Wu, Y., Zhao Lu, Cui, Y., Liu, H., Wang, S., Du, X., Zhao, C., Mao, J. Research on the relationship between team cooperation, work ability and team performance of nursing staff. Chinese hospital management, 2018,38(07):67-69.

[17] Zhu, X., Chen, Q., Yang, R. Chinese journal of health policy research, 2015,8(11):57-62. 